\title{
31. COCCOLITHS AND SILICOFLAGELLATES FROM DEEP SEA DRILLING PROJECT LEG 19, NORTH PACIFIC OCEAN AND BERING SEA ${ }^{1}$
}

\author{
David Bukry, U.S. Geological Survey, La Jolla, California
}

\section{INTRODUCTION}

Leg 19 of the Deep Sea Drilling Project, July-September, 1971, from Kodiak to Yokohama, recovered 238 cores at eleven drilling sites in the Bering Sea and North Pacific (Figure 1). As coccoliths and silicoflagellates are sparse in these cores, only 106 samples were taken during the drilling for study by this laboratory. Light-microscope techniques were used to examine the coccoliths and silicoflagellates in smear slides from these samples. Although most of them do contain abundant and diversified diatom assemblages, the small numbers of coccoliths and silicoflagellates represent only a few cold-water species that together indicate deposition at high latitude. Some silicoflagellates from Leg 19 samples are illustrated in Plates 1 and 2.

The sparse coccoliths are represented by so few species that for most samples only general age assignments can be indicated by them. Long-ranging and cosmopolitan placoliths are dominant. Although Cenozoic coccoliths range in age from early Eocene (Discoaster lodoensis Zone) to late Pleistocene (Gephyrocapsa oceanica Zone), many coccoliths typical at low and middle latitudes are absent or rare. Species of Discoaster and Sphenolithus are rare, and species of Ceratolithus, Discolithina, Helicopontosphaera, Rhabdosphaera, Scyphosphaera, Sphenolithus, and Triquetrorhabdulus are absent. In the Late Cretaceous (Campanian) calcareous sediment of Hole 192A, only a few solutionresistant coccoliths are present. Most of the coccoliths present in Leg 19 samples have been moderately to strongly etched and broken specimens are common, indicating preservation stage -3 to -4 (Bukry, 1973).

Silicoflagellate assemblages in the samples examined are distinguished by a predominance of the cool-water genus Distephanus over warm-water Dictyocha. The shape of Distephanus speculum, the principal species of the genus, is altered from low-latitude relatives. High-latitude populations have a high proportion of a form that has short spines and a large apical ring. This is presumably an intraspecific phenotypic response to colder surface water at high latitude. In the equatorial Pacific, the genus Cannopilus occurs in a restricted stratigraphic interval at the end of its range within the Pliocene. At the middle-latitude Site 173, this genus is largely restricted to the middle Miocene. And at Leg 19 drill sites and elsewhere in the North Pacific (Ling, 1970), Cannopilus disappears in the late Miocene. These occurrences suggest paleoecologic control on the occurrence of the Cannopilus association across latitude.

\footnotetext{
${ }^{1}$ Publication authorized by the Director, U.S. Geological Survey.
}

\section{SITE 183 \\ (lat. $52^{\circ} 34.30^{\prime} \mathrm{N}$, long. $161^{\circ} 12.33^{\prime} \mathrm{W}$, depth $4708 \mathrm{~m}$ )}

Site 183, at the northern margin of the Aleutian Abyssal Plain in the Gulf of Alaska, was intended to determine the lithostratigraphic and biostratigraphic record of this area through the Cenozoic. No samples were available to me from the Neogene diatom-rich section of Cores 1 to 21 (0 to $210 \mathrm{~m}$ ) or the barren clays of Cores 22 to 24 ( 210 to $239 \mathrm{~m})$. Some etched and poorly diversified coccolith assemblages are present in the Paleogene interval of Cores 25 to 39 (248 to $501 \mathrm{~m})$, but most samples examined are barren. The core catcher sample of Core 25 contains common coccoliths of only about five species of placoliths. The usual array of discoasters, sphenoliths, or helicopontosphaerids associated with placoliths at low and middle latitudes are missing. A predominance of placoliths in Paleogene assemblages from subarctic and subantarctic areas (Bukry, 1972, S.W. Wise, personal communication) suggests a similar high-latitude deposition for the Core 25 assemblage. The two most prominent placolith species in Core 25 are large, strongly etched Dictyococcites bisectus, which typically ranges from late Eocene to late Oligocene, and small, slightly to moderately etched Reticulofenestra? sp., which has no useful stratigraphic significance. The contrasting preservation stages suggest possible mixing, as does the drilling record. Nine meters was cored but less than 0.5 meter was recovered after applying pump pressure to penetrate "limestone." The assemblages of Cores 29 and 30 are composed only of individual specimens of the named species (Table 1). Both samples are essentially noncalcareous, and in the case of Core 29, the four specimens are part of a single sediment clump. The deepest sample in Core 39 is an ooze of strongly etched (-4) placoliths. Rim fragments and specimens with irregularly etched margins and central areas are abundant. Among the few species present, the overlapping typical ranges of Dictyococcites bisectus and Reticulofenestra umbilica indicate a late Eocene or early Oligocene age. No discoasters are present. Owing to diagenesis, cosmopolitan Chiasmolithus spp. present lack complete crossbars, but $C$. grandis [early to middle Eocene], which has a diagnostic rim structure, is absent, suggesting the sediment is no older than late Eocene.

\section{SITE 184 \\ (lat. $53^{\circ} 42.64^{\prime} \mathrm{N}$, long. $170^{\circ} 55.39^{\prime} \mathrm{W}$, depth $1910 \mathrm{~m}$ )}

No samples available; see reports of shipboard scientists. 


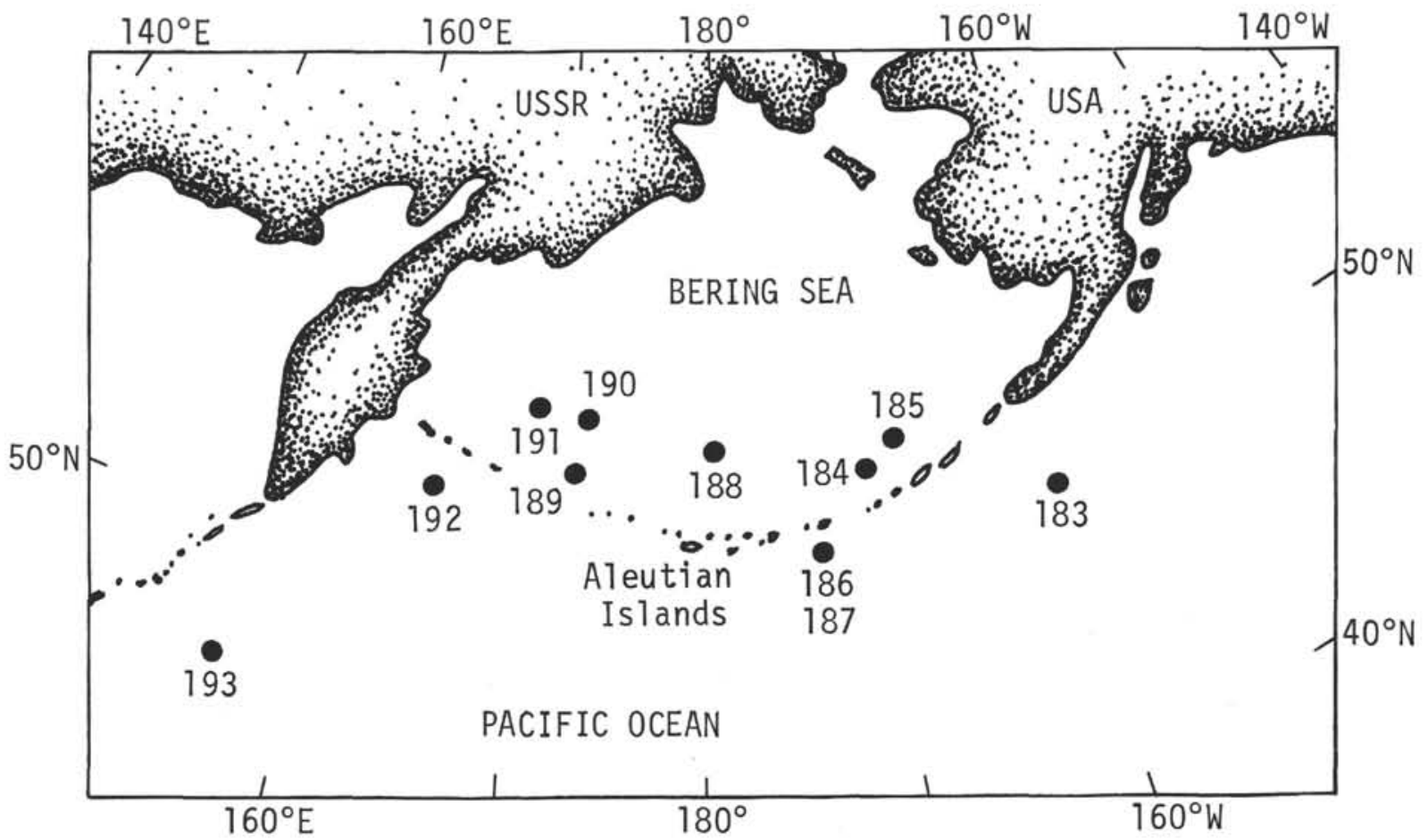

Figure 1. Sites cored during Deep Sea Drilling Project Leg 19.

TABLE 1

Occurrence of Coccoliths in Smear Slides of Samples from Site 183. Specimens are Strongly Etched.

\begin{tabular}{|c|c|c|c|c|c|c|}
\hline & & \multicolumn{5}{|c|}{ Species } \\
\hline Age & Sample (Depth) & 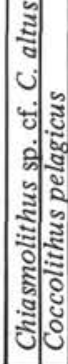 & 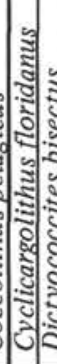 & : & : & : \\
\hline \multirow{6}{*}{ Oligocene } & $25(\mathrm{CC})(248 \mathrm{~m})$ & $\mathrm{x}$ & $\mathrm{x}$ & $\mathrm{x} x$ & $\mathrm{X}$ & \\
\hline & $26(\mathrm{CC})(257 \mathrm{~m})$ & & & & & \\
\hline & $27(\mathrm{CC})(267 \mathrm{~m})$ & & & & & \\
\hline & $28(\mathrm{CC})(276 \mathrm{~m})$ & & & & & \\
\hline & $29(\mathrm{CC})(285 \mathrm{~m})$ & & $x$ & & & $\begin{array}{ll}\mathrm{x} & \mathrm{x} \\
\end{array}$ \\
\hline & $30(\mathrm{CC})(295 \mathrm{~m})$ & & $\mathrm{x}$ & & & $\mathrm{x}$ \\
\hline \multirow{4}{*}{ ? } & $31(\mathrm{CC})(304 \mathrm{~m})$ & & & & & \\
\hline & $32(\mathrm{CC})(322 \mathrm{~m})$ & & & & & \\
\hline & $33(\mathrm{CC})(350 \mathrm{~m})$ & & & & & \\
\hline & $34(\mathrm{CC})(369 \mathrm{~m})$ & & & & & \\
\hline \multirow{4}{*}{$\begin{array}{l}\text { Early } \\
\text { Oligocene } \\
\text { or }\end{array}$} & $35(\mathrm{CC})(397 \mathrm{~m})$ & & & & & \\
\hline & $36(\mathrm{CC})(425 \mathrm{~m})$ & & & & & \\
\hline & $37(\mathrm{CC})(453 \mathrm{~m})$ & & & & & \\
\hline & $38(\mathrm{CC})(481 \mathrm{~m})$ & $\mathrm{X}$ & & & & \\
\hline $\begin{array}{l}\text { Late } \\
\text { Eocene }\end{array}$ & $\begin{array}{l}39-1(111-112 \\
\mathrm{cm})(501 \mathrm{~m})\end{array}$ & $\mathrm{x}$ & $\mathrm{x}$ & & & $\mathrm{X}$ \\
\hline
\end{tabular}

\section{SITE 185}

(lat. $54^{\circ} 25.73^{\prime} \mathrm{N}$, long. $169^{\circ} 14.59^{\prime} \mathrm{W}$, depth $2110 \mathrm{~m}$ )

A total of 27 cores ( 0 to $728 \mathrm{~m}$ ) were cut at this site in the south-eastern Bering Sea. Samples were available from the upper seven cores $(0$ to $138 \mathrm{~m})$, which are primarily silty diatom ooze of Pleistocene age. The only definitive coccolith species identified, Coccolithus pliopelagicus, occurs only in Sample 185-3-1 (100-101 cm). Digitate radial arrays of calcite that have typically been disaggregated into individual elements are common in Sample $185-4-4(70-71 \mathrm{~cm})$. Some of these arrays resemble the form of coccolith genera Cyclococcolithina and Gephyrocapsa, but no specimens of unquestioned identity were observed. Detailed study by electron microscopy might determine the inorganic or organic form of this material. The lack in this sample of any specimen of Coccolithus pliopelagicus, which is usually present in high-latitude Pleistocene assemblages, makes the coccolithic origin of the material questionable.

Silicoflagellates are sparse in the smear slides examined, except in $185-7-3(70-71 \mathrm{~cm})$, where Distephanus speculum s. 1. is common. The only other species observed, Distephanus polyactis, is represented by a few specimens having either seven or eight spines. The D. speculum s. 1 . specimens in this cold-water association are distinguished from warm-water forms by shorter spines and a much larger apical ring. The specimens of $D$. polyactis are similar in form to those observed from the Panama Basin (Bukry and Foster, 1973) but in this and other Leg 19 sites are more common. Species occurrence is shown in Table 2 . 
TABLE 2

Occurrence of Coccoliths and Silicoflagellates in Smear Slides of Samples from Site 185

\begin{tabular}{|c|c|c|c|c|}
\hline & & & peci & \\
\hline Age & Sample (Depth) & 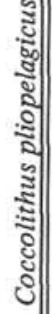 & 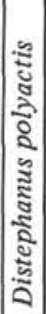 & 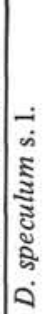 \\
\hline & $1-1(70-71 \mathrm{~cm})(1 \mathrm{~m})$ & & & \\
\hline & $14(70-71 \mathrm{~cm})(5 \mathrm{~m})$ & & & \\
\hline & $2-1(70-71 \mathrm{~cm})(10 \mathrm{~m})$ & & & \\
\hline & $3-1(100-101 \mathrm{~cm})(17 \mathrm{~m})$ & $\mathrm{x}$ & & $\mathrm{X}$ \\
\hline & $4-2(70-71 \mathrm{~cm})(37 \mathrm{~m})$ & & $\mathrm{X}$ & $\mathrm{X}$ \\
\hline Pleistocene & $4-4(70-71 \mathrm{~cm})(40 \mathrm{~m})$ & & $\mathrm{X}$ & \\
\hline & $5-2(70-71 \mathrm{~cm})(65 \mathrm{~m})$ & & $\mathrm{X}$ & \\
\hline & $6-2(70-71 \mathrm{~cm})(93 \mathrm{~m})$ & & $\mathrm{X}$ & $\mathrm{X}$ \\
\hline & $6-4(70-71 \mathrm{~cm})(96 \mathrm{~m})$ & & & \\
\hline & $7-1(110-111 \mathrm{~cm})(130 \mathrm{~m})$ & & & $\mathrm{X}$ \\
\hline & $7-3(70-71 \mathrm{~cm})(132 \mathrm{~m})$ & & & $\mathrm{X}$ \\
\hline
\end{tabular}

\section{SITE 186}

\section{(lat. $51^{\circ} 07.81^{\prime} \mathrm{N}$, long. $174^{\circ} 00.34^{\prime} \mathrm{W}$, depth $4522 \mathrm{~m}$ )}

Site 186 is in the Atka Basin south of the Aleutian Islands. A Pleistocene to middle(?) Miocene diatom-rich section was sampled in Cores 1 to 28 ( 0 to $926 \mathrm{~m})$. A single sample available from this site, $186-23-3(100-101 \mathrm{~cm})(621$ $\mathrm{m})$, contains rare coccoliths and silicoflagellates that together suggest a pre-late Miocene age. Coccoliths include Coccolithus pelagicus, Dictyococcites sp. cf. D. scrippsae, and Cyclicargolithus floridanus, which typically has a last occurrence in the middle Miocene. The silicoflagellates include Clathropyxidella sp. cf. C. similis, Mesocena triangula, and Naviculopsis lata. Specimens of the latter two species are identical in form to those illustrated by Bachmann (1970) from the upper Oligocene of Austria. On the basis of these six taxa the sample is probably late Oligocene to middle(?) Miocene in age.

\section{SITE 187}

(lat. $51^{\circ} 06.6^{\prime} \mathrm{N}$, long. $173^{\circ} 57.2^{\prime} \mathrm{W}$, depth $4567 \mathrm{~m}$ )

No samples available; see the reports of shipboard scientists.

\section{SITE 188}

(lat. $53^{\circ} 45.21^{\prime} \mathrm{N}$, long. $178^{\circ} 39.56^{\prime} \mathrm{E}$, depth $2649 \mathrm{~m}$ )

Site 188 is on Bowers Ridge north of the Aleutian Islands. Cores 1 to $18(0$ to $638 \mathrm{~m})$ sampled a diatom-rich Miocene to Pleistocene section. Samples were available from the upper eight cores $(0$ to $236 \mathrm{~m})$, which are Pleistocene. Coccoliths are present in only two samples. Etched specimens of Coccolithus pelagicus and Gephyrocapsa caribbeanica in Core 5 provide the only evidence for a Pleistocene age based on coccoliths at this site. Silicoflagellates are rare in all samples examined. Eight-spined varieties of Distephanus polyactis are typical of the Pleistocene here as at Site 185: In Core 7, seven- and nine-spined varieties also are present. Species occurrence is shown in Table 3. The uncommon silicoflagellate Distephanus slavnicii (Jerković) [basionym: Dictyocha slavnici slavnici Jerković, 1965. Lab. Micropaleont., Inst. Paleont. Museum, Paris. p. 5 , pl. 1, fig. 18 ; pl. 2 , fig. 10 ] was noted only as a single specimen.

\section{SITE 189}

(lat. $54^{\circ} 02.14^{\prime} \mathrm{N}$, long. $170^{\circ} 13.38^{\prime} \mathrm{E}$, depth $3437 \mathrm{~m}$ )

Site 189 is at the crest of the Aleutian-Kormandorski Ridge north of the Aleutian Arc. Twenty cores were cut ( 0 to $871 \mathrm{~m}$ ). A diatom-bearing silty clay of Pleistocene and Pliocene age in Cores 1 to $8(0$ to $370 \mathrm{~m})$ is reported to overlie a poorly fossiliferous lower section. One sample each was available from the upper six cores. Coccoliths of Pelistocene age, Coccolithus pelagicus, C. pliopelagicus, and Gephyrocapsa oceanica occur only in Sample 189-1-1 $(95-96 \mathrm{~cm})(1 \mathrm{~m})$. Among silicoflagellates, only sparse Distephanus polyactis was noted in a single sample, 189-4-2 $(40-41 \mathrm{~cm})(84 \mathrm{~m})$.

\section{SITE 190}

(lat. $55^{\circ} 33.55^{\prime} \mathrm{N}$, long. $171^{\circ} 38.42^{\prime} \mathrm{E}$, depth $3875 \mathrm{~m}$ )

Site 190 is in the southwestern part of the Aleutian Basin. Diatom-rich clays of Pleistocene to Miocene age constitute most of the sediment recovered in Cores 1 to 16 $(0$ to $627 \mathrm{~m})$. One sample from each of the upper nine cores ( 0 to $121 \mathrm{~m}$ ) was available. No coccoliths are present. Silicoflagellates occur in the smear slides for Cores 4,6 , and 8. Sample $190-4-1(70-71 \mathrm{~cm})(25 \mathrm{~m})$ contains a few Distephanus speculum and rare D. octangulatus and $D$.

TABLE 3

Occurrence of Coccoliths and Silicoflagellates in Smear Slides of Samples from Site 188

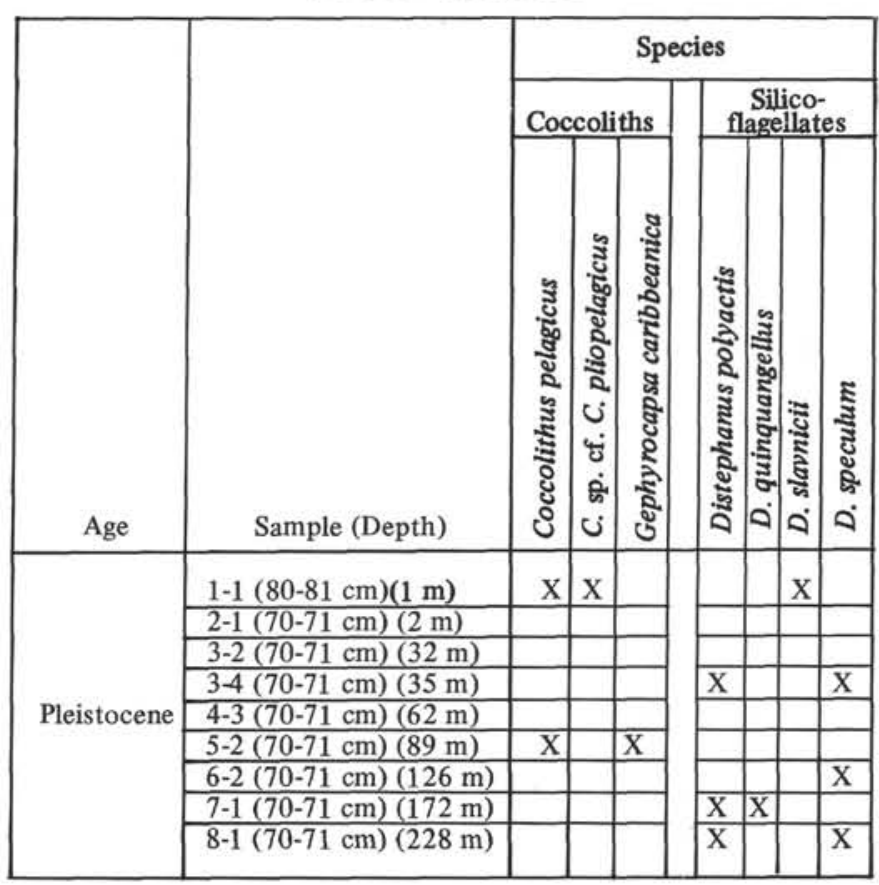


polyactis, a Pleistocene association. Only rare $D$. speculum was noted in Samples 190-6-3 $(70-71 \mathrm{~cm})(47 \mathrm{~m})$ and $190-8-3(70-71 \mathrm{~cm})(87 \mathrm{~m})$.

\section{SITE 191}

(lat. $56^{\circ} 56.70^{\prime} \mathrm{N}$, long. $168^{\circ} 10.72^{\prime} \mathrm{E}$, depth $3854 \mathrm{~m}$ )

Of the twenty cores ( 0 to $919 \mathrm{~m}$ ) in the abyssal plain of the Kamchatka Basin west of the Shirshov Ridge, samples were available from four. Three of the samples proved barren of coccoliths and silicoflagellates: 191-2-2 (60-61 cm) $(2 \mathrm{~m})$; 191-5-6 (80-81 cm) $(142 \mathrm{~m})$; and 191-8-2 (70-71 $\mathrm{cm})(176 \mathrm{~m})$. In Sample 191-4-1 $(60-61 \mathrm{~cm})(79 \mathrm{~m})$, a few specimens of both Distephanus polyactis and D. speculum are present. The proportions of the spines and apical ring of $D$. speculum are more typical than those at Site 185 . Eight-spined varieties of $D$. polyactis are more common than the seven- or nine-spined varieties, a characteristic Pleistocene association for this region.

\section{SITE 192 \\ (lat. $53^{\circ} 00.57^{\prime} \mathrm{N}$, long. $164^{\circ} 42.81^{\prime} \mathrm{E}$, depth $3014 \mathrm{~m}$ )}

Site 192 is at the northwest end of the Emperor Seamount chain where the Kuril and Aleutian trenches join. Coring was intended to help assess high-latitude calcareous plankton stratigraphy and to obtain evidence of relative motion for plate tectonic theory. A total of 41 cores $(0$ to $1057 \mathrm{~m}$ ) were cut in two holes at this site, Hole 192 and Hole 192A. Coccoliths are rare or absent except in Pleistocene Cores 1 to 4 ( 0 to $28 \mathrm{~m}$ ), Oligocene Cores 34 to 35 and $1 \mathrm{~A}$ (922 to $951 \mathrm{~m})$, and Eocene Cores $4 \mathrm{~A}$ to $5 \mathrm{~A}$ 1018 to $1053 \mathrm{~m}$ ). In all of these, poorly diversified assemblages have been altered by etching or overgrowth. The oldest assemblages of Campanian age (Core 5A, at $1043-1053 \mathrm{~m}$ ) are composed of rare specimens in a matrix of fine calcareous debris. Occurrences of coccoliths and silicoflagellates in the samples available from this site are shown in Tables 4 and 5.

Pleistocene coccolith assemblages of Cores 1 to 2 are characterized by an abundance of Coccolithus pliopelagicus having very narrow and elongate central areas and by rare specimens of Gephyrocapsa oceanica and Cyclococcolithina leptopora. In Core 4 only a few $C$. pliopelagicus and small ?Gephyrocapsa producta are present. The majority of the specimens show etched margins or breakage indicating -3 preservation. Etching of the central-area margin of $C$. pliopelagicus produces a digitate pattern. The small number of species present is attributed to the limited diversity of living populations in high latitudes (Fischer, 1960; Hasle, 1960; Stehli et al., 1969) in addition to strong solution of calcium carbonate in cold, undersaturated waters.

Coccoliths are absent in samples from Cores 5 to $17(28$ to $334 \mathrm{~m}$ ), which are dated as Pliocene and late Miocene by siliceous microfloras. Only a few strongly etched (-4), poorly diversified assemblages are present from Cores 18 to $33(353-922 \mathrm{~m})$. The species present are all long ranging and cosmopolitan.

The calcareous sediment of the interval of Cores 34, 35, and 1A typically contains a coccolith assemblage dominated by fragmented specimens of long-ranging Paleogene placoliths. The zonal marker species of low and middle latitude areas are absent, for example, no Discoaster, Helicopontosphaera, or definitive Sphenolithus occur. The ecologic exclusion of solution-resistant Discoaster and Sphenolithus is typical of high-latitude assemblages. Among the placoliths, the combination of Chiasmolithus sp., Cyclicargolithus floridanus, and Dictyococcites bisectus indicates an Eocene or Oligocene age. Rare specimens of Isthmolithus recurvus and Reticulofenestra hillae in Core $1 \mathrm{~A}$ indicate the late Eocene or Oligocene. The absence of two other solution-resistant species which generally characterize this stratigraphic interval, Cyclococcolithina formosa and Reticulofenestra umbilica, suggests high-latitude deposition at Site 192 even then. The most stratigraphically diagnostic coccolith assemblages at Site 192 are from the lower part of Core 4A, where the Discoaster lodoensis Zone of early Eocene age occurs. The placoliths Chiasmolithus sp. cf. C. grandis, Coccolithus magnicrassus, and Cyclicargolithus pseudogammation [basionym: Coccolithus(?) pseudogammation Bouché, 1962, Rev. Micropaléontologie, 5, p. 84 , pl. 1, figs. 19-20], occur with Discoaster barbadiensis, $D$. sp. cf. D. distinctus, D. lodoensis, and Tribrachiatus orthostylus, a typical oceanic assemblage of this zone. The irregular and overgrown preservation state $(+3)$ and the abundance of broken specimens is similar to that in lower Eocene red argillites from onshore and offshore areas of the Pacific northwest.

Rare specimens of Broinsonia parca, Cylindralithus sp. cf. C. gallicus, and Tetralithus gothicus in Core 5A indicate the Late Cretaceous (Campanian). A paucity of species and specimens prevents a more refined assignment.

Silicoflagellate assemblages are most abundant and diverse in Cores 12 to 22 ( 232 to $531 \mathrm{~m})$, which according to diatom correlations are late Miocene in age. The association of silicoflagellates such as Cannopilus spp. and Mesocena elliptica present here has been used to indicate the Miocene in the north Pacific (Ling, 1970; Bukry, in preparation). In the equatorial Pacific, the same species of Cannopilus occur only in sediments which are Pliocene in age (Jousé, 1969, Bukry and Foster, 1973), indicating that the Cannopilus association is time transgressive. The occurrence of the genus is probably temperature dependent, with both lower and upper temperature thresholds. Species common to Site $192\left(53^{\circ} \mathrm{N}\right)$, Site $172\left(40^{\circ} \mathrm{N}\right)$, and Site $157\left(2^{\circ} \mathrm{S}\right)$, include: Cannopilus binoculus, C. hemisphaericus, $C$. major, and $C$. quintus. Most of these species could have developed from the Distephanus speculum group. Silicoflagellates are most common at Site 192 in the samples from Cores 13 and 16 , and the dominance of Cannopilus and Distephanus indicate cold-water deposition. Relative abundances based on a count of 200 specimens for Core 13 are $61 \%$ Distephanus speculum, $16 \%$ D. polyactis, $14 \%$ Cannopilus major, 6\% Mesocena diodon, 4\% M. elliptica, $<1 \%$ Cannopilus binoculus, and $<1 \%$ Mesocena triodon nom. nov. [substitute name for Mesocena elliptica triangula Bachmann and Ichikawa, 1962, Kanazawa Univ. Science Repts., 3, p. 168, pl. 1, figs. 3, 10]. Relative abundances based on a count of 53 specimens for Core 16 are 30\% Distephanus quinquangellus, $19 \%$ D. speculum, 19\% Dictyocha pentagona, 15\% Cannopilus major, 9\% C. binoculus, and $8 \%$ Mesocena elliptica. Silicoflagellates are rare below Core 22 . 
TABLE 4

Occurrence of Coccoliths in Smear Slides of Samples Available from Hole 192

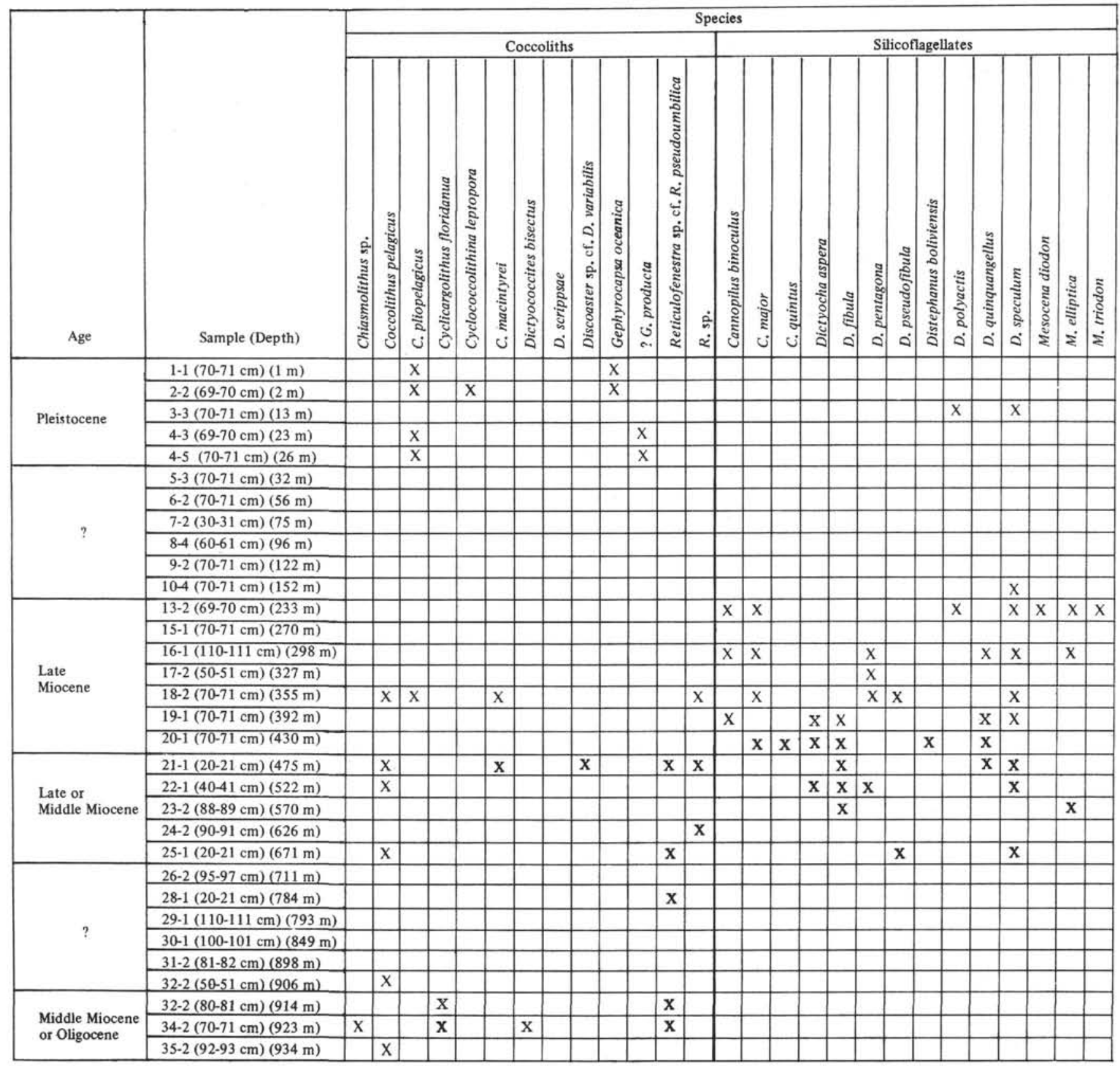

\section{SITE 193}

(lat. $45^{\circ} 48.20^{\prime} \mathrm{N}$, long. $155^{\circ} 52.27^{\prime} \mathrm{E}$, depth $4811 \mathrm{~m}$ )

No samples available; see the reports of shipboard scientists.

\section{REFERENCES}

Bachmann, A., 1970. Silicoflagellaten aus dem oberösterreichischen Egerien (Oberoligozän). Osterreichische Geol. Bundesanst. Verh. 2, 275.

Bukry, D., 1972. Further comments on coccolith stratigraphy, Leg 12, Deep Sea Drilling Project. In Laughton, A. S., Berggren, W. A. et al., 1972. Initial Reports of the Deep Sea Drilling Project, Volume XII. Washington (U.S. Government Printing Office). 1071.
1973. Coccolith stratigraphy, Eastern Equatorial Pacific, Leg 16 Deep Sea Drilling Project. In van Andel, Tj. H., Heath, G. R. et al. Initial Reports of the Deep Sea Drilling Project, Volume XVI. Washington (U.S. Government Printing Office).

, in preparation. Coccolith and Silicoflagellate stratigraphy, Deep Sea Drilling Project Leg 18, eastern North Pacific. In Kulm, L. D., von Heune, R. et al. Initial Reports of the Deep Sea Drilling Project, Volume XVIII. Washington (U.S. Government Printing Office).

Bukry, D. and Foster, J.H., 1973. Silicoflagellate and diatom stratigraphy, Leg 16, Deep Sea Drilling Project. In van Andel, Tj. H., Heath, G. R. et al. Initial Reports of the Deep Sea Drilling Project, Volume XVI. Washington (U.S. Government Printing Office). 
Occurrence of Coccoliths in Smear Slides of Samples Available from Hole 192A

\begin{tabular}{|c|c|c|c|c|c|c|c|c|c|c|c|c|c|c|c|c|c|c|c|c|c|c|c|c|c|c|c|c|c|c|c|}
\hline \multirow[b]{3}{*}{ Age } & \multirow[b]{3}{*}{ Sample (Depth) } & \multicolumn{30}{|c|}{ Species } \\
\hline & & \multicolumn{6}{|c|}{ Coccoliths } & \multicolumn{24}{|c|}{ Silicoflagellates } \\
\hline & & 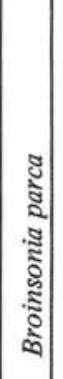 & 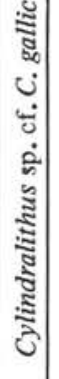 & 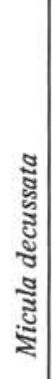 & 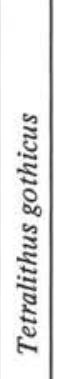 & 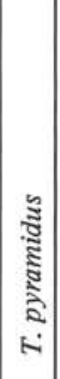 & 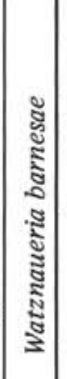 & 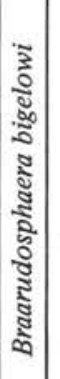 & 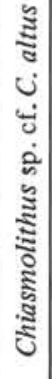 & 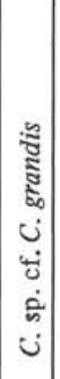 & 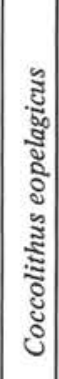 & 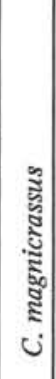 & 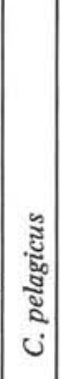 & 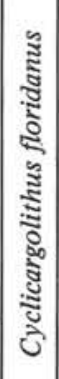 & 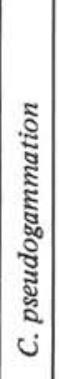 & 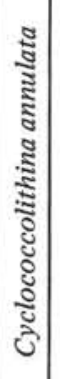 & $\begin{array}{c}: \\
\vdots \\
\vdots \\
\vdots \\
ن \\
ن\end{array}$ & 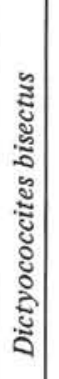 & 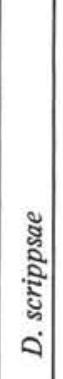 & 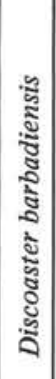 & 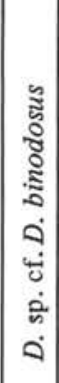 & 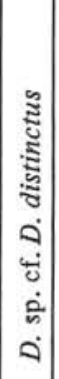 & 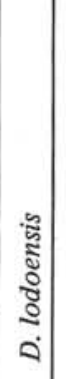 & $\dot{2}$ & 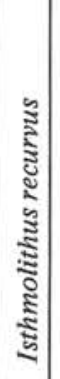 & 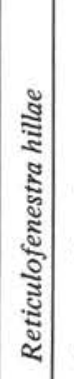 & 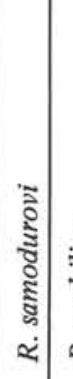 & 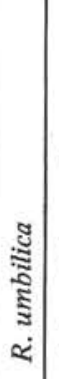 & 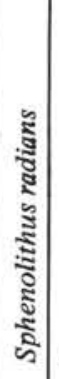 & $\begin{array}{l}\dot{2} \\
\dot{\omega}\end{array}$ & 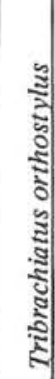 \\
\hline \multirow{7}{*}{$\begin{array}{l}\text { Oligocene or } \\
\text { Late Eocene }\end{array}$} & $1 \mathrm{~A}-1(105-106 \mathrm{~cm})(943) \mathrm{m})$ & & & & & & & & $\mathrm{x}$ & & $\mathrm{x}$ & & $\mathrm{x}$ & $\mathrm{x}$ & & & & $\mathrm{x}$ & & & & & & & & $\mathrm{x}$ & & & & $\mathrm{x}$ & \\
\hline & $1 \mathrm{~A}-2(77-78 \mathrm{~cm})(944 \mathrm{~m})$ & & & & & & & & & & & & & $\mathrm{x}$ & & & & $\mathrm{X}$ & & & & & & & & $\mathrm{x}$ & & & & & \\
\hline & $1 \mathrm{~A}-3(38-39 \mathrm{~cm})(945 \mathrm{~m})$ & & & & & & & & & & & & & $\mathrm{x}$ & & & & $\mathrm{x}$ & & & & & & & & $\mathrm{X}$ & & & & & \\
\hline & $1 \mathrm{~A}-4(65-66 \mathrm{~cm})(947 \mathrm{~m})$ & & & & & & & & $\mathrm{x}$ & & $\mathrm{x}$ & & & & & & & $\mathrm{x}$ & $\mathrm{x}$ & & & & & & & $\mathrm{x}$ & & & & & \\
\hline & $1 \mathrm{~A}-5(80-81 \mathrm{~cm})(949 \mathrm{~m})$ & & & & & & & & & & & & $\mathrm{x}$ & & & & & $\mathbf{x}$ & $\mathrm{x}$ & & & & & & $\mathrm{X}$ & $\mathrm{x}$ & & & & & \\
\hline & $1 \mathrm{~A}-6(53-54 \mathrm{~cm})(950 \mathrm{~m})$ & & & & & & & & & & & & & $\mathrm{x}$ & & & & $\mathrm{x}$ & $\mathrm{X}$ & & & & & & & & & & & & \\
\hline & $2 \mathrm{~A}-1(74-75 \mathrm{~cm})(951 \mathrm{~m})$ & & & & & & & & & & & & & $\mathrm{x}$ & & & & $\mathrm{x}$ & & & & & & & & $\mathrm{x}$ & & & & & \\
\hline \multirow{4}{*}{ ? } & $2 \mathrm{~A}-2(54-56 \mathrm{~cm})(953 \mathrm{~m})$ & & & & & & & & & & & & & & & & & & & & & & & & & & & & & & \\
\hline & $2 \mathrm{~A}-3(62-63 \mathrm{~cm})(954 \mathrm{~m})$ & & & & & & & & & & & & & & & & & & & & & & & & & & & & & & \\
\hline & $2 \mathrm{~A}-4(94-95 \mathrm{~cm})(956 \mathrm{~m})$ & & & & & & & & & & & & & & & & & & & & & & & & & & & & & & \\
\hline & $2 \mathrm{~A}-5(103-104 \mathrm{~cm})(958 \mathrm{~m})$ & & & & & & & & & & & & & & & & & & & & & & & & & & & & & & \\
\hline \multirow{5}{*}{ Middle Eocene } & $2 \mathrm{~A}-6(125-126 \mathrm{~cm})(960 \mathrm{~m})$ & & & & & & & & & & & & & & & & & & & & & & & & & & & $\mathrm{x}$ & & & \\
\hline & $3 \mathrm{~A}-2(90-90 \mathrm{~cm})(984 \mathrm{~m})$ & & & & & & & & & & & & & $\mathrm{x}$ & & & & & $\mathrm{x}$ & & & & & & & & & $\mathrm{x}$ & & & \\
\hline & $3 \mathrm{~A}-3(90-90 \mathrm{~cm})(986 \mathrm{~m})$ & & & & & & & & & & & & & & & & & & & & & & & & & & & & & & \\
\hline & 4A-1 $(75-76 \mathrm{~cm})(1019 \mathrm{~m})$ & & & & & & & & $\mathrm{x}$ & & & & $\mathrm{x}$ & & & & & & $\mathrm{x}$ & & & & & & & & \begin{tabular}{l|l}
$\mathbf{x}$ & 2 \\
\end{tabular} & $\mathrm{x}$ & & & \\
\hline & 4A-2 $(95-97 \mathrm{~cm})(1020 \mathrm{~m})$ & & & & & & & & $\mathrm{x}$ & & $\mathrm{x}$ & & & & & $\mathrm{x}$ & $\mathrm{x}$ & & $\mathrm{x}$ & & & & & $\mathrm{x}$ & & & \begin{tabular}{l|l}
$\mathbf{x}$ & 2 \\
\end{tabular} & $\mathrm{X}$ & & & \\
\hline \multirow{2}{*}{ Early Eocene } & $4 \mathrm{~A}-3(115-116 \mathrm{~cm})(1022 \mathrm{~m})$ & & & & & & & $\mathrm{x}$ & & $\mathrm{x}$ & & & $\mathrm{x}$ & & $\mathrm{x}$ & & & & & $\mathrm{x}$ & & $\mathrm{x}$ & $\mathrm{x}$ & & & & & & $\mathrm{x}$ & & $\mathrm{X}$ \\
\hline & $4 \mathrm{~A}-4(72-73 \mathrm{~cm})(1023 \mathrm{~m})$ & & & & & & & & & $\mathbf{x}$ & & $\mathrm{x}$ & $\mathrm{x}$ & & & & & & & $\mathrm{x}$ & $\mathrm{x}$ & & $\mathrm{x}$ & & & & & & & $\mathbf{x}$ & $\mathrm{x}$ \\
\hline \multirow{2}{*}{$\begin{array}{l}\text { Late Cretaceous } \\
\text { (Campanian) }\end{array}$} & $5 \mathrm{~A}-0(4-5 \mathrm{~cm})(1043 \mathrm{~m})$ & $\mathrm{x}$ & $\mathrm{X}$ & $\mathrm{x}$ & $\mathrm{x}$ & $\mathrm{x}$ & $\mathrm{x}$ & & & & & & & & & & & & & & & & & & & & & & & & \\
\hline & $5 \mathrm{~A}-1(70-71 \mathrm{~cm})(1044 \mathrm{~m})$ & $\mathrm{x}$ & & $\mathrm{x}$ & & $\mathrm{x}$ & $\mathbf{x}$ & & & & & & & & & & & & & & & & & & & & & & & & \\
\hline
\end{tabular}


Fischer, A.G., 1960. Latitudinal variations in organic diversity. Evolution. 14, 64.

Hasle, G.R., 1960. Plankton coccolithophorids from the subantartic and equatorial Pacific. Nytt Mag. Botanikk. 8,77 .

Jousé, A.P., 1969. Silikoflyagellyaty v donnykh osadkakh Pleistotsena i pozdnego Pliotsena Tihovo Okeana [Silicoflagellates in bottom sediments of Pleistocene and late
Pliocene of the Pacific Ocean]. In A.P. Jousé (Ed.), Micropaleontology and organogenous sedimentation in the oceans. "Nauka" Publishing Office, Moscow. 105.

Ling, H-Y., 1970. Silicoflagellates from central North Pacific core sediments. Bull. Am. Paleontol. 58, 85.

Stehli, F.G., Douglas, R.G. and Newell, N.D., 1969 Generation and maintenance of gradients in taxonomic diversity. Science. 164, 947. 


\section{PLATE 1}

Silicoflagellates from DSDP Leg 19

Photomicrographs magnified $500 \mathrm{X}$ Scale bar equals 10 microns

Figures 1-3 Cannopilus major (Frenguelli)

1. Sample 192-16-1(110-111)(298 m).

2-3. Sample 192-13-2(69-70 cm) $(233 \mathrm{~m})$.

Figure $4 \quad$ Dictyocha sp. cf. D. aspera (Lemmermann) Sample 192-19-1(70-71 cm) $(392 \mathrm{~m})$.

Figure 5 Dictyocha pentagona (Schulz) Sample 192-16-1(110-111 cm) $(298 \mathrm{~m})$.

Figures 6-7 Distephanus octangulatus Wailes Sample 190-4-1(70-71 cm) $(25 \mathrm{~m})$.

6. High focus.

7. Low focus.

Figures 8-10 Distephanus polyactis (Ehrenberg)

8. Sample $188-7-1(70-71 \mathrm{~cm})(172 \mathrm{~m})$.

9. Sample $185-4-4(70-71 \mathrm{~cm})(40 \mathrm{~m})$.

10. Sample $190-4-1(70-71 \mathrm{~cm})(25 \mathrm{~m})$.

Figure 11-12 Distephanus quinquangellus Bukry and Foster Sample 192-16-1(110-111 cm) $(298 \mathrm{~m})$.

11. High focus.

12. Low focus. 

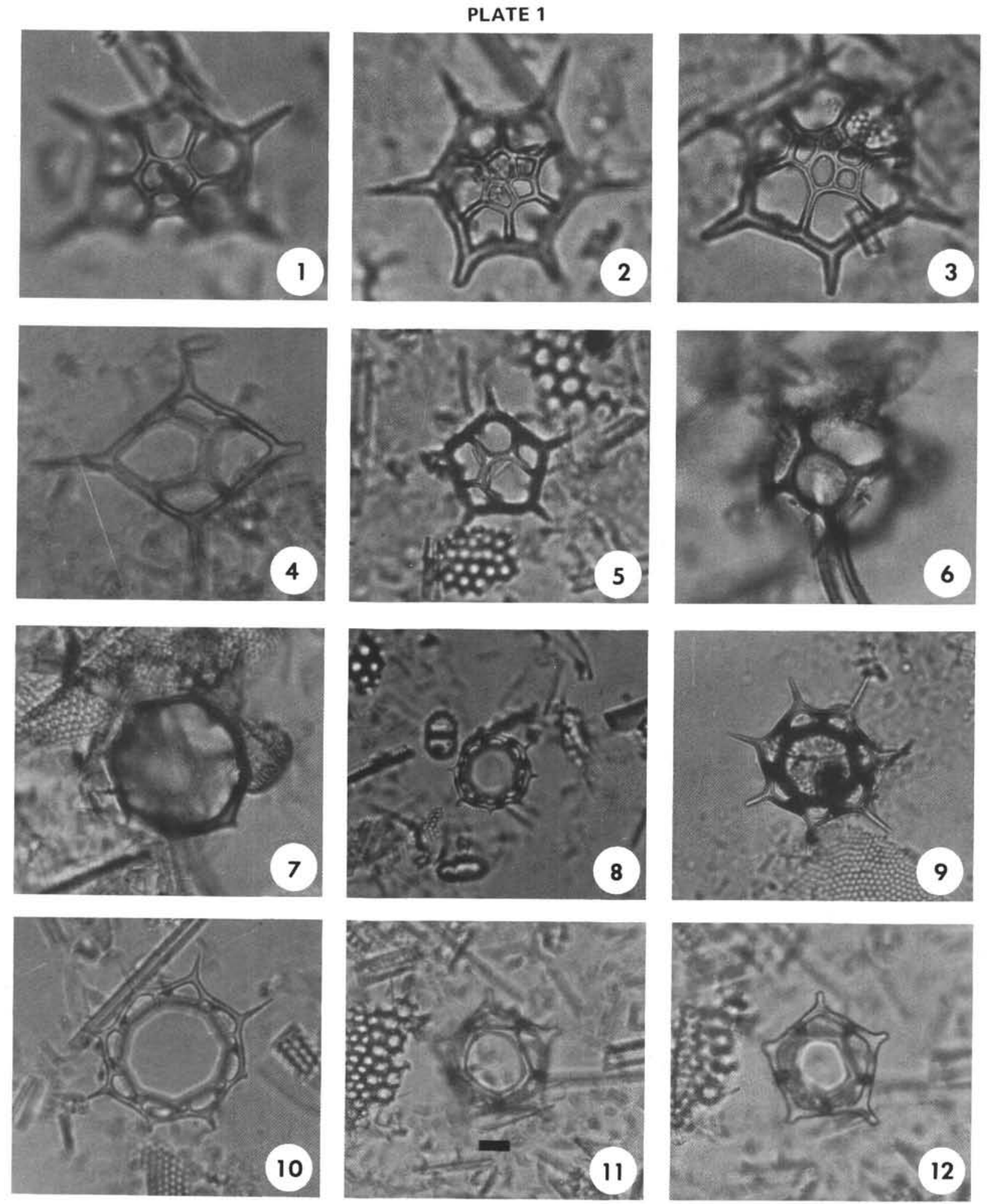


\section{PLATE 2}

Silicoflagellates from DSDP Leg 19

Photomicrographs magnified $500 \mathrm{X}$ Scale bar equals 10 microns

Figures 1-2 Distephanus slavnicii (Jerković)

Sample 188-1-1 $(80-81 \mathrm{~cm})(1 \mathrm{~m})$.

1. High focus.

2. Low focus.

Figures 3-5 Distephanus speculum (Ehrenberg)

3. Sample 190-6-3(70-71 cm) $(47 \mathrm{~m})$.

4-5. Sample $190-4-1(70-71 \mathrm{~cm})(25 \mathrm{~m})$.

Figures 6-7 Mesocena diodon Ehrenberg

Sample 192-13-2 $(69-70 \mathrm{~cm})(233 \mathrm{~m})$.

Figures 8-9 Mesocena elliptica (Ehrenberg)

8. Sample 192-13-2(69-70 cm) $(233 \mathrm{~m})$.

9. Sample 192-16-1(110-111 cm) $(298 \mathrm{~m})$.

Figure 10 Mesocena triangula (Ehrenberg)

Sample 186-23-3(100-101 cm) $(621 \mathrm{~m})$.

Figure $11 \quad$ Mesocena triodon Bukry

Sample 192-13-2 $(69-70 \mathrm{~cm})(233 \mathrm{~m})$.

Figure $12 \quad$ Naviculopsis lata (Deflandre)

Sample 186-23-3(100-101 cm) $(621 \mathrm{~m})$. 

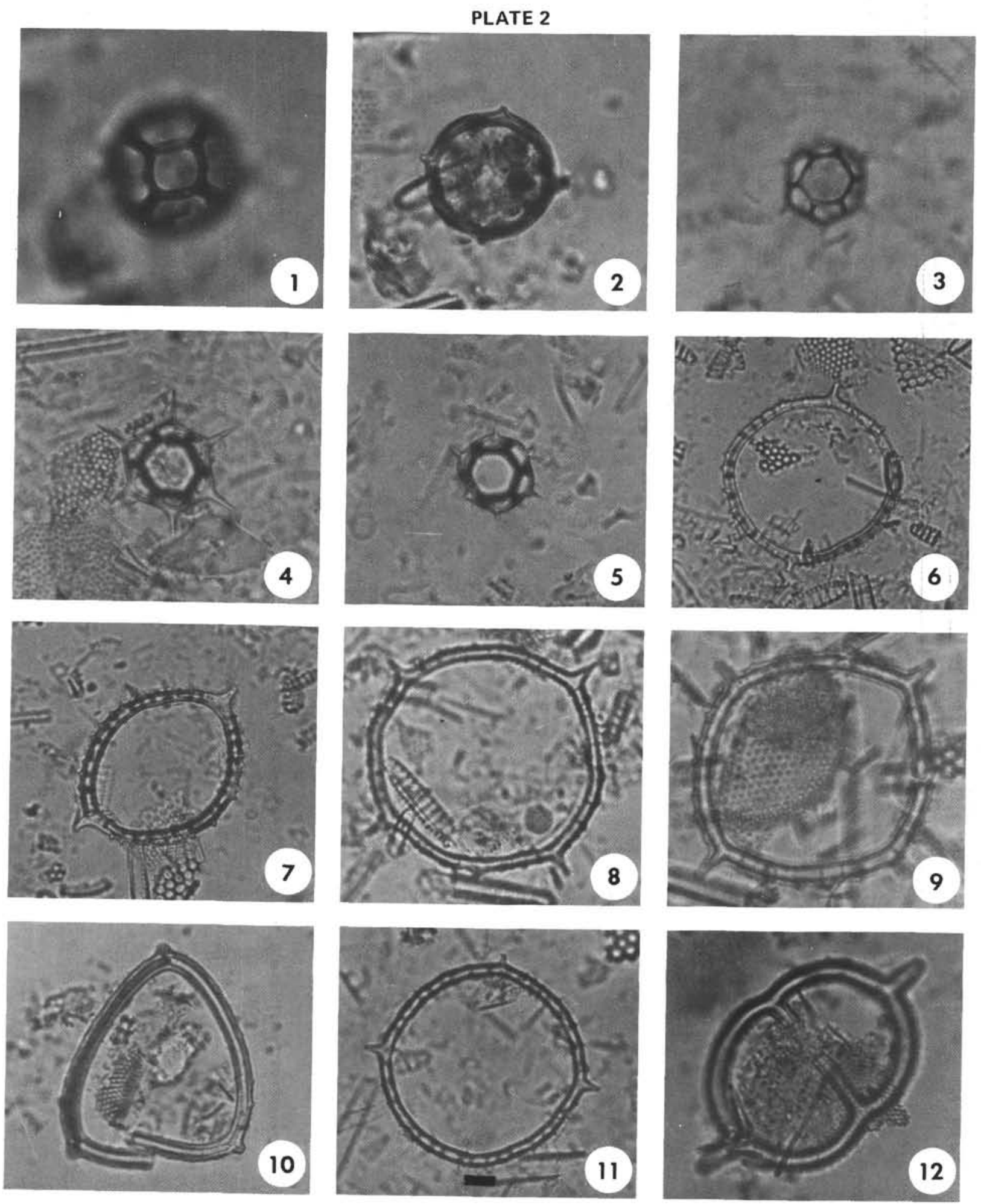